Research Article

\title{
Preparation, Characterization, and Application of Novel Ferric Oxide-Amine Material for Removal of Nitrate and Phosphate in Water
}

\author{
Trung Thanh Nguyen (D, , ${ }^{1,2}$ Tri Thich Le, ${ }^{1,2,3}$ Phuoc Toan Phan, ${ }^{2,3,4}$ \\ and Nhat Huy Nguyen (iD) \\ ${ }^{1}$ Laboratory of Nanomaterials, An Giang University, 18 Ung Van Khiem St., Dong Xuyen Ward, Long Xuyen City, \\ An Giang Province, Vietnam \\ ${ }^{2}$ Vietnam National University Ho Chi Minh City, Linh Trung Ward, Thu Duc District, Ho Chi Minh City, Vietnam \\ ${ }^{3}$ Faculty of Environment and Natural Resources, Ho Chi Minh City University of Technology (HCMUT), 268 Ly Thuong Kiet St., \\ Dist. 10, Ho Chi Minh City, Vietnam \\ ${ }^{4}$ Faculty of Engineering - Technology - Environment, An Giang University, 18 Ung Van Khiem St., Dong Xuyen Ward, \\ Long Xuyen City, An Giang Province, Vietnam
}

Correspondence should be addressed to Trung Thanh Nguyen; ntthanh@agu.edu.vn and Nhat Huy Nguyen; nnhuy@hcmut.edu.vn

Received 10 January 2020; Revised 1 April 2020; Accepted 7 April 2020; Published 24 April 2020

Academic Editor: Franck Rabilloud

Copyright (C) 2020 Trung Thanh Nguyen et al. This is an open access article distributed under the Creative Commons Attribution License, which permits unrestricted use, distribution, and reproduction in any medium, provided the original work is properly cited.

\begin{abstract}
Ferric oxide-amine material was synthesized and applied as a novel adsorbent for nitrate and phosphate removal from aqueous solution. The properties of ferric oxide-amine were examined using TGA, FTIR, BET, SEM, EDX, SEM-mapping, and XRD analysis. The results showed that the adsorption using ferric oxide-amine material reached equilibrium after 30 and 60 min for nitrate and phosphate, respectively. The highest nitrate and phosphate adsorption capacities were $131.4 \mathrm{mg}$ nitrate/g at pH 5-6 and $42.1 \mathrm{mg}$ phosphate/g at $\mathrm{pH}$ 6. The effects of adsorbent dosage, initial concentrations of nitrate and phosphate, and adsorption temperature were also investigated. Among the three adsorbents of ferric oxide-amine, ferric oxide, and Akualite A420 ion exchange resin, ferric oxide-amine material had the highest adsorption capacity for nitrate and phosphate removal. These results suggest a great potential use of ferric oxide-amine material for water treatment in practical applications.
\end{abstract}

\section{Introduction}

Water pollution due to the excessive presence of nitrogen and phosphorus compounds is one of the most frequently faced environmental problems around the world. This is due to the ineffective wastewater treatment and overuse of nitrogen and phosphorus fertilizers in agriculture. High concentrations of nitrate $\left(\mathrm{NO}_{3}{ }^{-}\right)$and phosphates $\left(\mathrm{PO}_{4}{ }^{3-}\right)$ are considered as the main cause of eutrophication [1]. Besides, high level of $\mathrm{NO}_{3}{ }^{-}$is also one of the risks to human health. It can cause some health problems such as methemoglobinemia, or $\mathrm{NO}_{3}{ }^{-}$can be converted into nitrosamine (toxic nitrite), which is the reason for increasing the risk of cancer [2].

Many biological, chemical, and physical processes have been applied to remove $\mathrm{NO}_{3}{ }^{-}$and $\mathrm{PO}_{4}{ }^{3-}$ from water and wastewater [3-6]. In particular, the adsorption process by the ion exchange mechanism is evaluated as an effective, simple, and low-cost method, in which the adsorbent is capable of being recycled many times [7]. Therefore, ion exchange resins have been widely studied in recent years [8-10]. Common materials (e.g., activated carbon, rice husk ash, and bamboo charcoal) and engineered nanomaterials (e.g., iron-carbon oxide nanotube [11] and chitosan $/ \mathrm{Al}_{2} \mathrm{O}_{3} /$ 
$\left.\mathrm{Fe}_{3} \mathrm{O}_{4}[12]\right)$ are quite effective for removing $\mathrm{NO}_{3}{ }^{-}$and $\mathrm{PO}_{4}{ }^{3-}$. However, because of low adsorption capacity, complicated process, and high cost, they have not been employed for practical applications yet. Therefore, a study on the development of a new, inexpensive, and efficient material for simultaneous removal of nitrate and phosphate in water is appreciated.

In this study, ferric oxide was used as a support for synthesis of ferric-amine oxide. The material was then characterized and applied to remove $\mathrm{NO}_{3}{ }^{-}$and $\mathrm{PO}_{4}{ }^{3-}$ in water. The suitable conditions of $\mathrm{NO}_{3}{ }^{-}$and $\mathrm{PO}_{4}{ }^{3-}$ adsorption in solution such as $\mathrm{pH}$, contact time, adsorbent dosage, initial concentration, and temperature were determined. Besides, the ability of the material was compared to the original ferric oxide and commercial material available in the market.

\section{Materials and Methods}

2.1. Chemicals. Lab-grade chemicals such as $\mathrm{FeCl}_{3} \cdot 6 \mathrm{H}_{2} \mathrm{O}$ and urea were from China while $\mathrm{H}_{2} \mathrm{SO}_{4}, \mathrm{NaOH}, \mathrm{KNO}_{3}, \mathrm{KH}_{2} \mathrm{PO}_{4}$, N1-(3-trimethoxysilylpropyl) diethylenetriamine (triamine silane), toluene, and pentane were from Merck. Industrialgrade Akualite A420 resin was from China and DI (deionized) water was from a local water machine in the lab. The nitrate and phosphate aqueous solutions were prepared by dissolving a certain amount of $\mathrm{KNO}_{3}$ and $\mathrm{KH}_{2} \mathrm{PO}_{4}$ in DI water.

2.2. Synthesis of Ferric Oxide-Amine. Ferric oxide nanomaterial was prepared by a process adopted from the work of Raul et al. [13, 14]. Typically, $12.5 \mathrm{~g}(0.1 \mathrm{M})$ of $\mathrm{Fe}_{2}\left(\mathrm{SO}_{4}\right)_{3} \cdot 5 \mathrm{H}_{2} \mathrm{O}$ was dissolved into $250 \mathrm{~mL}$ of double distilled water in a beaker. The beaker was stirred, heated using a magnetic stirrer until the temperature of the solution reached $60^{\circ} \mathrm{C}$, and let for $30 \mathrm{~min}$. The solution was then added dropwise to $250 \mathrm{~mL}$ of $5.0 \mathrm{M}$ urea solution within $3.5 \mathrm{~h}$ under a temperature of $70^{\circ} \mathrm{C}$ for complete reaction. After that, the temperature was increased to $80^{\circ} \mathrm{C}$ and maintained until the volume of the solution reduced to half of the initial volume. Subsequently, the brown precipitate formed after cooling the solution to room temperature $\left(25 \pm 01^{\circ} \mathrm{C}\right)$ was washed repeatedly to remove the excess urea. Finally, the powder form of ferric oxide/hydroxide nanoparticles was obtained after drying the washed precipitate in an oven at $70^{\circ} \mathrm{C}$ for $4 \mathrm{~h}$.

Ferric oxide-amine was prepared according to a process previously published by Thanh [15]. Ferric oxide was fed into a glass flask containing $150 \mathrm{~mL}$ of toluene under stirring for obtaining a homogeneous mixture. Subsequently, $0.3 \mathrm{~mL}$ of distilled water per each gram of ferric oxide was added to the flask and mixed for $30 \mathrm{~min}$. The flask was then soaked in a silicone oil bath at $85^{\circ} \mathrm{C}$. After that, the mixture was added to triamine silane ( $3 \mathrm{~mL}$ per 1 gram of ferric oxide) for $16 \mathrm{~h}$. After filtering and washing with toluene and pentane, the ferric oxide-amine material was collected and dried at $100^{\circ} \mathrm{C}$ for $1 \mathrm{~h}$.

2.3. Characterizations. The morphology of ferric oxideamine was observed by scanning electron microscopy (SEM) while the various elemental compositions of ferric oxideamine were determined by energy dispersive X-ray analysis (EDX). The surface chemical properties were characterized by Fourier transform infrared spectroscopy (FTIR; Alpha, Bruker). The phase transformation and thermal decomposition of ferric oxide-amine were evaluated by thermogravimetric analysis (TGA, Q500 machine). The specific surface area was determined by the Brunauer-Emmett-Teller method (Porous Materials, BET-202A).

2.4. Batch Adsorption Experiments. The effect of contact time was carried out by adding $30 \mathrm{mg}$ of adsorbent to $50 \mathrm{~mL}$ of $50 \mathrm{mg} / \mathrm{L}$ nitrate solution or $10 \mathrm{mg} / \mathrm{L}$ phosphate solution with adsorption time from 0 to $120 \mathrm{~min}$. The mixture was then filtrated and the water sample was taken for analysis of nitrate and phosphate concentration by UV-visible spectrophotometry. The influencing parameters including contact time, adsorbent dosage, solution $\mathrm{pH}$, initial adsorbate concentration, and temperature were investigated. The adsorption capacity was calculated as follows:

$$
Q_{e}=\frac{C_{0}-C_{t}}{m} \times V
$$

where $Q_{\mathrm{e}}$ is the adsorption capacity $(\mathrm{mg} / \mathrm{g}) . C_{\mathrm{o}}$ and $C_{t}$ are the initial and final concentrations of nitrate or phosphate solution $(\mathrm{mg} / \mathrm{L})$, respectively. $m$ is the adsorbent weight $(\mathrm{g})$ and $V$ is the solution volume (L).

\section{Results and Discussion}

3.1. Characterization of Ferric Oxide-Amine. The surface functional groups of the materials are usually determined by FTIR [16]. In this study, the surface chemical structure of ferric oxide nanomaterials before and after adsorption was determined to clarify the reaction mechanism that occurred on the surface. As showed in Figure 1, all samples had a characteristic peak of $\mathrm{Fe}-\mathrm{O}$ bond that appeared at a wavenumber of $567 \mathrm{~cm}^{-1}$ [17] while triamine silane peaks were observed at wavenumbers of 1041 and $1122 \mathrm{~cm}^{-1}$ of Si-O in ferric oxide-amine samples $[17,18]$. Other peaks in the range of 3384 and $3442 \mathrm{~cm}^{-1}$ were considered as the overlapping of $\mathrm{N}-\mathrm{H}$ and $\mathrm{O}-\mathrm{H}$ groups of adsorbed water on the materials [18]. In addition, peaks of $-\mathrm{NH}_{2}$ appearing at $1626 \mathrm{~cm}^{-1}$ [19] and $1654 \mathrm{~cm}^{-1}$ [18] in ferric oxide-amine samples confirmed the effective grafting of amino groups to ferric oxide nanoparticles. After nitrate and phosphate adsorption, the new peaks appearing at 1384 and $908 \mathrm{~cm}^{-1}$ were considered to be of nitrate [20] and phosphate [21], respectively, proving that the ferric oxide-amine material can adsorb anions such as nitrate and phosphate.

The morphology of ferric oxide-amine and ferric oxide materials was examined by SEM. The flower-shaped structure observed from the attached bunches of ferric oxide in Figure 2(a) became smoother after being grafted by triamine silane (Figure 2(b)), and the particle size of the ferric oxide-amine material became larger than that of the original ferric oxide material. The amine grafting significantly reduces the specific surface area of the material from 


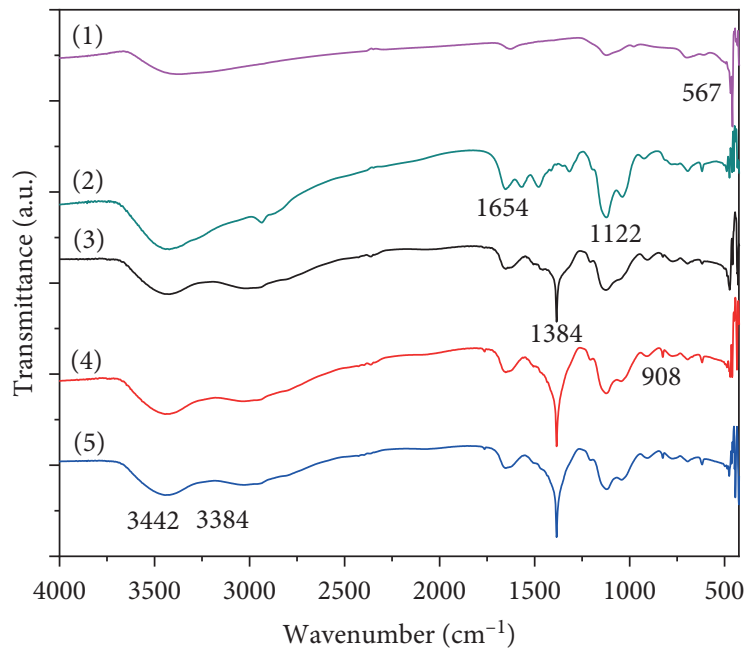

FIgURE 1: FTIR spectra of (1) ferric oxide, (2) fresh ferric oxide-amine, and used ferric oxide-amine after (3) nitrate adsorption, (4) phosphate adsorption, and (5) simultaneous nitrate and phosphate adsorption.

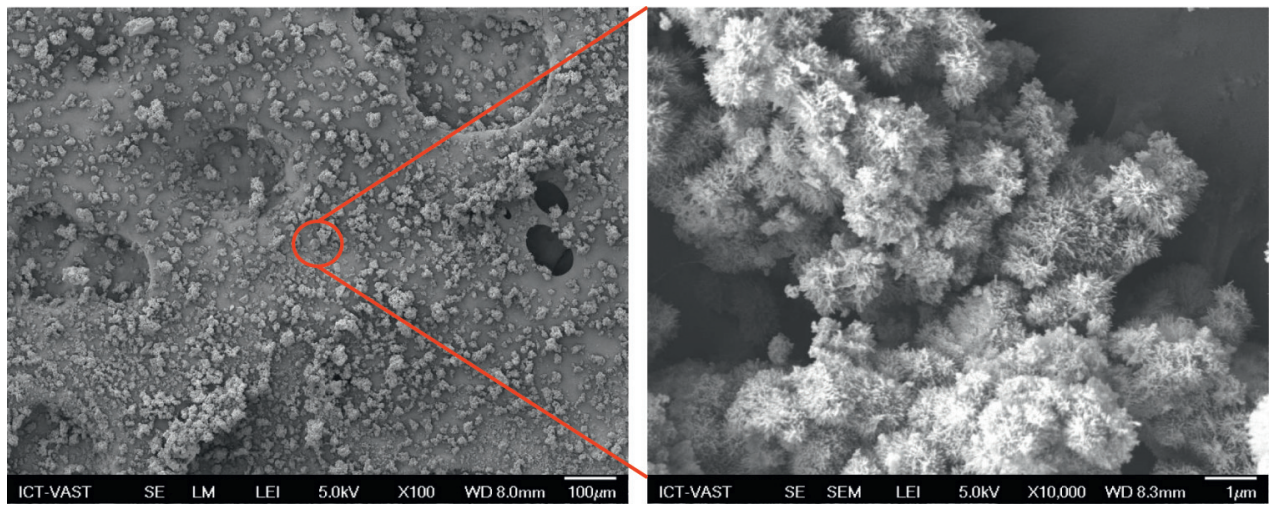

(a)

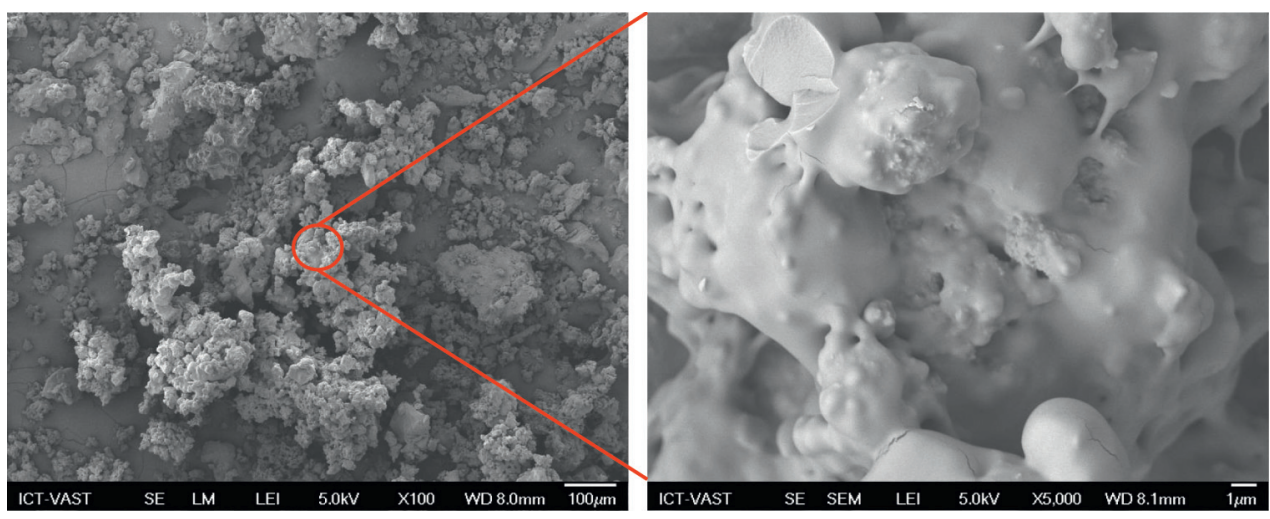

(b)

FIgURE 2: SEM images of (a) ferric oxide and (b) ferric oxide-amine.

$145.13 \mathrm{~m}^{2} / \mathrm{g}$ in ferric oxide to only $14.68 \mathrm{~m}^{2} / \mathrm{g}$ in ferric oxide material. In addition, this nearly 10 -time reduction in the surface area confirmed the effective grafting of a great amine amount on the surface of ferric oxide.

The phase transformation and chemical composition of ferric oxide and ferric oxide-amine samples were investigated by thermogravimetric analysis in a wide range of temperatures from $30^{\circ} \mathrm{C}$ to $900^{\circ} \mathrm{C}$. Results in Figure 3 showed that the weight reduction of ferric oxide and ferric oxide-amine was $37 \%$ and $56.63 \%$, respectively. There was a light fall in the weight of both materials ( $4 \%$ for ferric oxide and $6 \%$ for ferric oxide-amine) at the temperature of $80^{\circ} \mathrm{C}$ to $150^{\circ} \mathrm{C}$, which can be attributed to the release of moisture or dehydration. At $600^{\circ} \mathrm{C}$, the weight of ferric oxide changed 


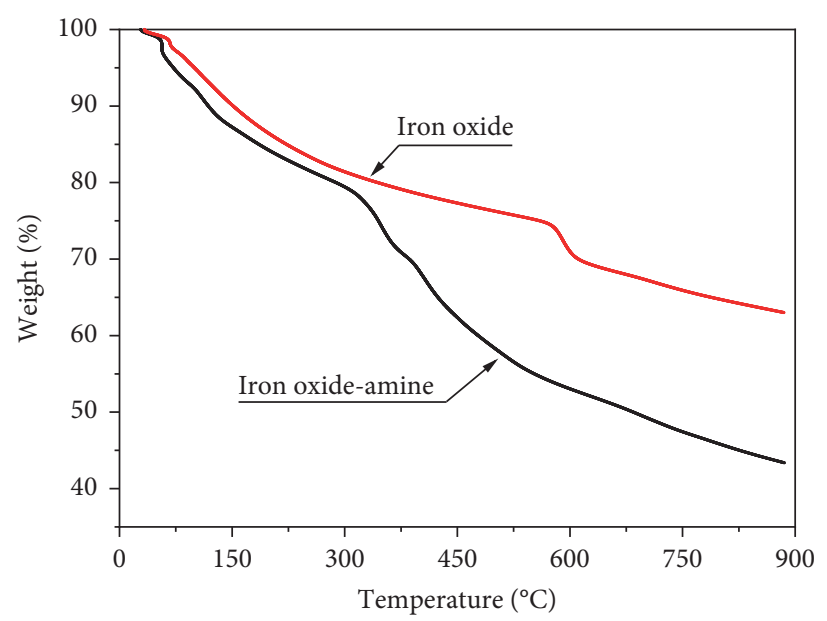

(a)

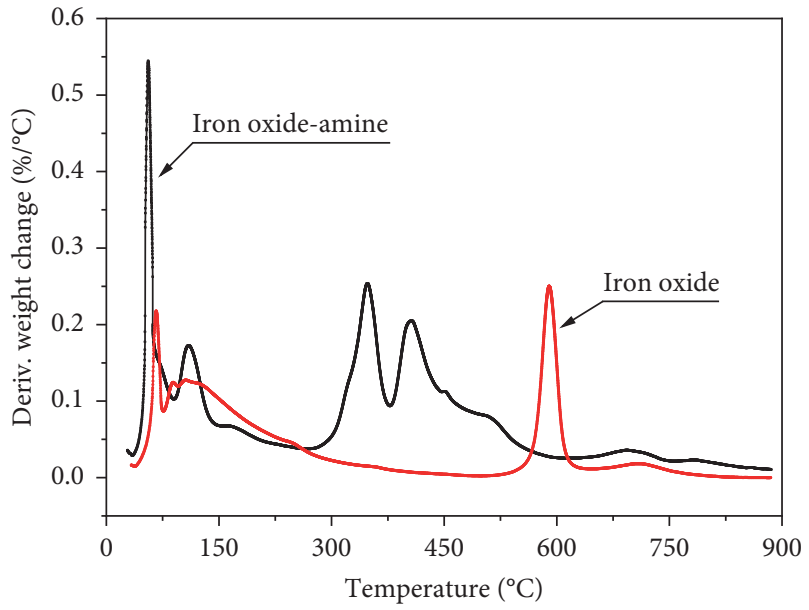

(b)

Figure 3: (a) TG and (b) DTG curves of ferric oxide-amine.

significantly, possibly because of ferric oxide in the form of $\gamma$-hematite (cubic structure) being converted to $\alpha$-hematite (hexagonal structure) $[22,23]$. In addition, the evaporation of water and organic matter in the structure along with the structural change of the ferric oxide occurred at the temperature of 300 and $500^{\circ} \mathrm{C}$, which resulted in the decline of ferric oxide-amine weight. The decrease in mass at a temperature of 300 to $350^{\circ} \mathrm{C}$ is due to the loss of structural water, and at 350 to $500^{\circ} \mathrm{C}$ due to the restructuring of the oxide and the burning temperature of grafted amine groups on the ferric oxide surface (see Figure 3(b)) [24, 25], proving that ferric oxide-amine material was successfully synthesized.

$\mathrm{X}$-ray diffraction spectra of ferric oxide and ferric oxideamine samples are plotted in Figure 4. The ferric oxide diffraction spectrum had obtuse-angle and low peaks, showing the relatively low crystallinity of the as-synthesized materials without any heat treatment step $[13,26]$, which was similar for the ferric oxide-amine sample. However, there was a peak with a wide range, and low intensity existed at a low diffraction angle of $20^{\circ}$ to $25^{\circ}$, which could be attributed to the presence of a very small amount of silicon oxide in the material [27-29].

EDX and SEM-mapping are two of the most commonly used techniques to evaluate the surface composition and the distribution of elements on the surface of the material. EDX spectrum and elemental mapping of ferric oxide-amine material are exhibited in Figure 5. The sample consists of five elements, which were evenly distributed on the surface of the material. The elemental weight percentage decreased in the order of silicon, carbon, iron, oxygen, and nitrogen, which reflects the amine content of the produced material.

\subsection{Adsorption of Nitrate and Phosphate onto Ferric Oxide-} Amine Material. As presented in Figure 6, the adsorption capacity of ferric oxide-amine increased with the increase of contact time during the test period of $120 \mathrm{~min}$. The adsorption equilibrium of nitrate adsorption was reached after $30 \mathrm{~min}$, which was faster than that of phosphate $(60 \mathrm{~min})$. This could

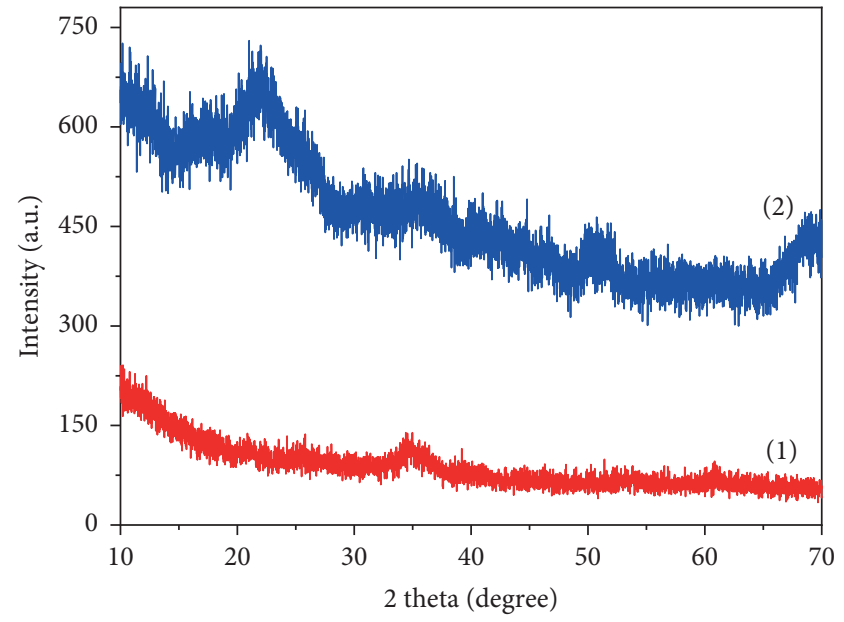

FIGURE 4: XRD patterns of (1) ferric oxide and (2) ferric oxideamine.

be explained by the stronger interaction of the aminofunctional groups with nitrate than that with phosphate [18]. The nitrate and phosphate adsorption capacity of ferric oxideamine were calculated at $100 \mathrm{mgNO}_{3}^{-} / \mathrm{g}$ and $40 \mathrm{mgPO}_{4}{ }^{3-} / \mathrm{g}$, respectively. For phosphate removal, the adsorption process has three stages: (i) a rapid increase for the first $30 \mathrm{~min}$ by the externally exposed surface of the amine group, (ii) a slow increase for the next $30 \mathrm{~min}$ by the internal ferric oxide surface, and (iii) reaching the equilibrium after $60 \mathrm{~min}$ when both external and internal surfaces become saturated.

Regarding kinetics study, the nitrate and phosphate adsorption on ferric oxide-amine material was determined by three kinetic models, consisting of pseudo-first-order, pseudo-second-order, and intraparticle diffusion models. The equilibrium adsorption capacity $\left(q_{e, \exp }\right)$ of the material was chosen to be $100.51 \mathrm{mgNO}_{3}{ }^{-} / \mathrm{g}$ for nitrate and $40.60 \mathrm{mgPO}_{4}{ }^{3-} / \mathrm{g}$ for phosphate as taken from the experimental data. Linear equations of kinetic models and correlation coefficients $\left(R^{2}\right)$ are shown in Table 1 and Figure 7. On this account, the pseudo-second-order model was 


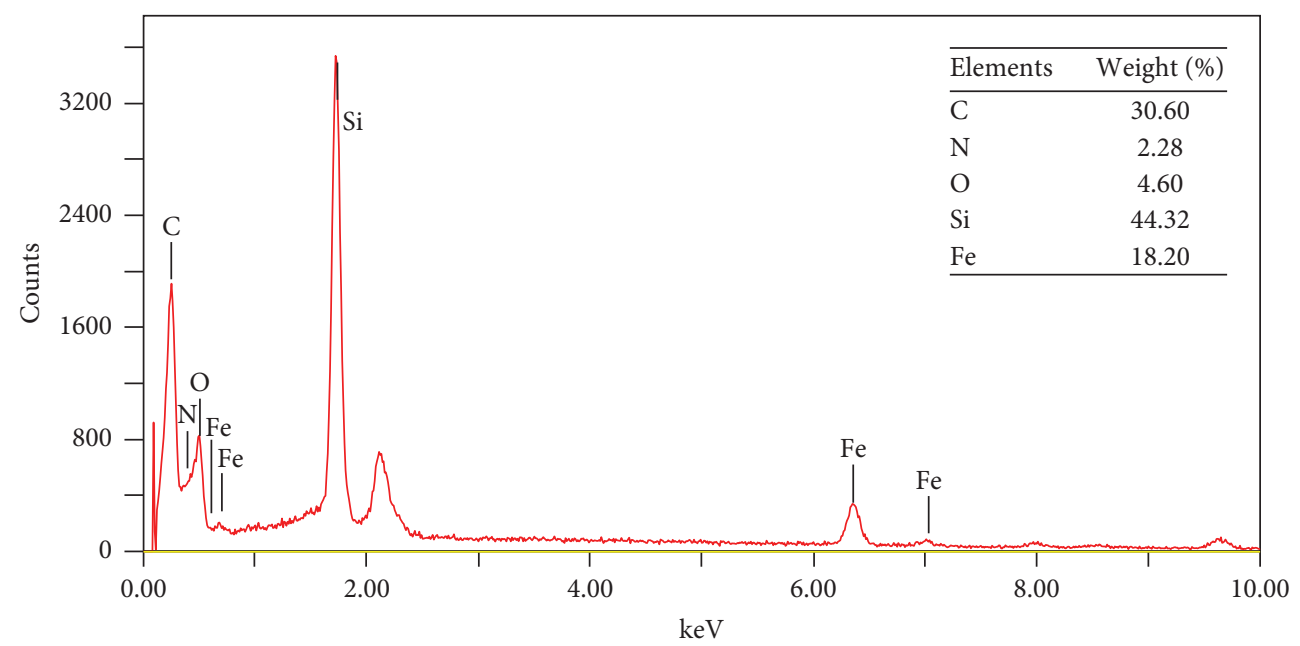

(a)
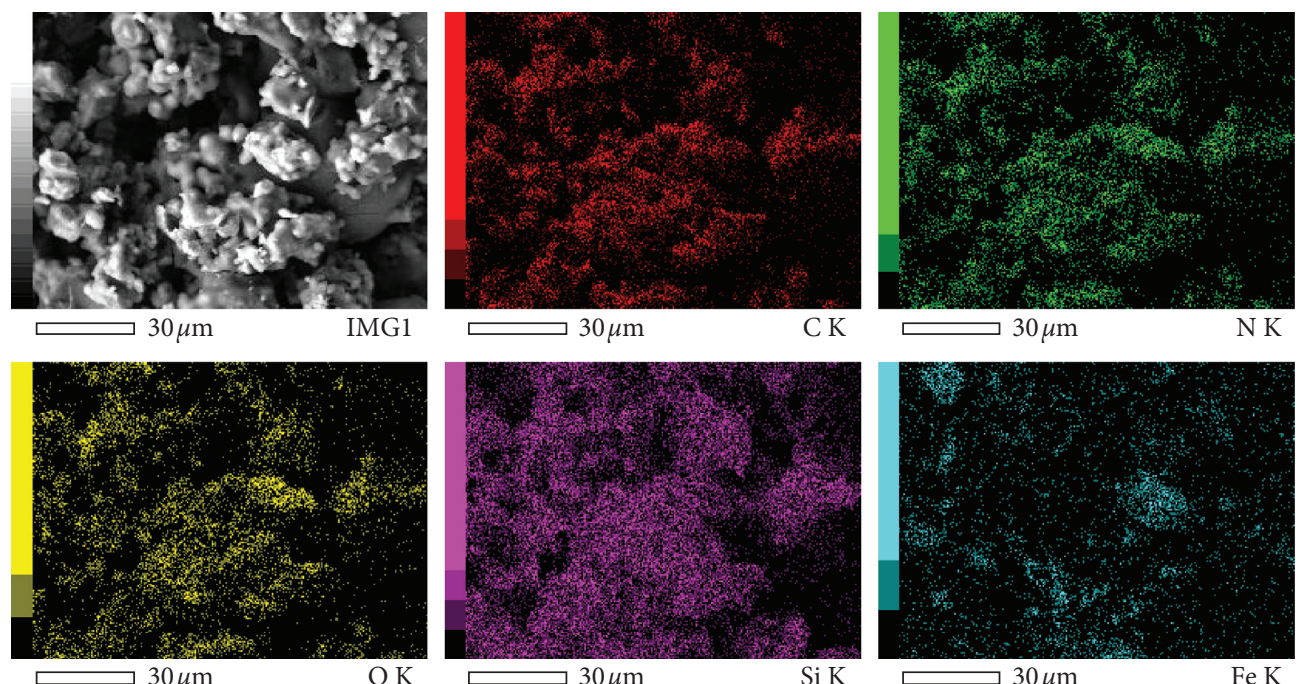

(b)

FIgURE 5: (a) EDX spectrum and (b) SEM image and elemental mapping of ferric oxide-amine.

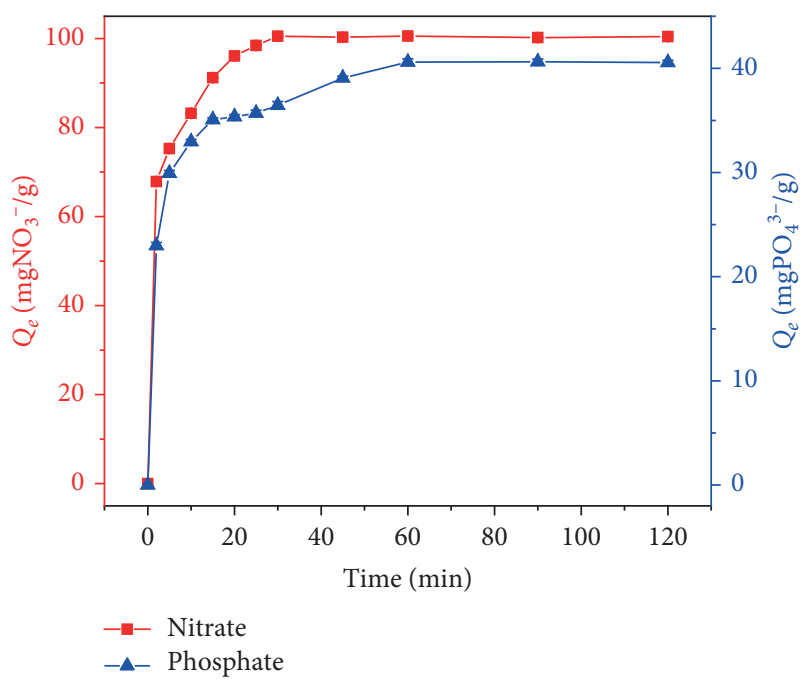

FIGURE 6: Effects of the contact time on nitrate and phosphate adsorption of ferric oxide-amine material. considered as the best-fit model to describe the adsorption with the greatest correlation coefficient among the others. Moreover, the calculated adsorption capacity $\left(q_{e}\right.$, cal $)$ approximated the experimental adsorption capacity $\left(q_{e, \exp }\right)$ and this was correct for both nitrate and phosphate. The adsorption rate constants $k$ were then determined to be 0.00924 (g/mg.min) with nitrate concentration of $50 \mathrm{mg} / \mathrm{L}$ and 0.00899 (g/mg.min) with phosphate concentration of $10 \mathrm{mg} / \mathrm{L}$.

It is observed in Figure 8(a) that changes in adsorption capacity of both nitrate and phosphate were followed by changes in solution $\mathrm{pH}$. The nitrate and phosphate adsorption capacity of ferric oxide-amine material reached a peak of over $130 \mathrm{mgNO}_{3}{ }^{-} / \mathrm{g}$ and $40 \mathrm{mgPO}_{4}{ }^{3-} / \mathrm{g}$ in the $\mathrm{pH}$ range of 5-6 and 6, respectively. Regarding nitrate, the increase of $\mathrm{H}^{+}$concentration at $\mathrm{pH}<5$ impeded the nitrate adsorption, and there is an adsorption competition with $\mathrm{SO}_{4}{ }^{2-}$ anion from $\mathrm{H}_{2} \mathrm{SO}_{4}$ used to adjust the solution $\mathrm{pH}$ [30]. At $\mathrm{pH}>6$, the nitrate adsorption capacity also decreased on 
TABLE 1: Correlation coefficients $\left(R^{2}\right)$ and linear equations of kinetic models for nitrate and phosphate adsorption on ferric oxide-amine material.

\begin{tabular}{lcccc}
\hline Ion & Kinetic model & Linear equation & $R^{2}$ & Capacity $\left(q_{e, \text { cal }}\right) \mathrm{mg} / \mathrm{g}$ \\
\hline \multirow{3}{*}{ Nitrate } & Pseudo-first-order & $y=0.0534 x+2.9705$ & 0.7849 & 18.73 \\
& Pseudo-second-order & $y=0.0098 x+0.0104$ & $\mathbf{0 . 9 9 9 7}$ & 102.04 \\
Intraparticle diffusion & $y=0.1027 x+4.1972$ & 0.8568 & - \\
Phosphate & Pseudo-first-order & $y=0.0461 x+2.8955$ & 0.9156 & 21.69 \\
& Pseudo-second-order & $y=0.0241 x+0.0646$ & $\mathbf{0 . 9 9 8 9}$ & 41.49 \\
\hline
\end{tabular}

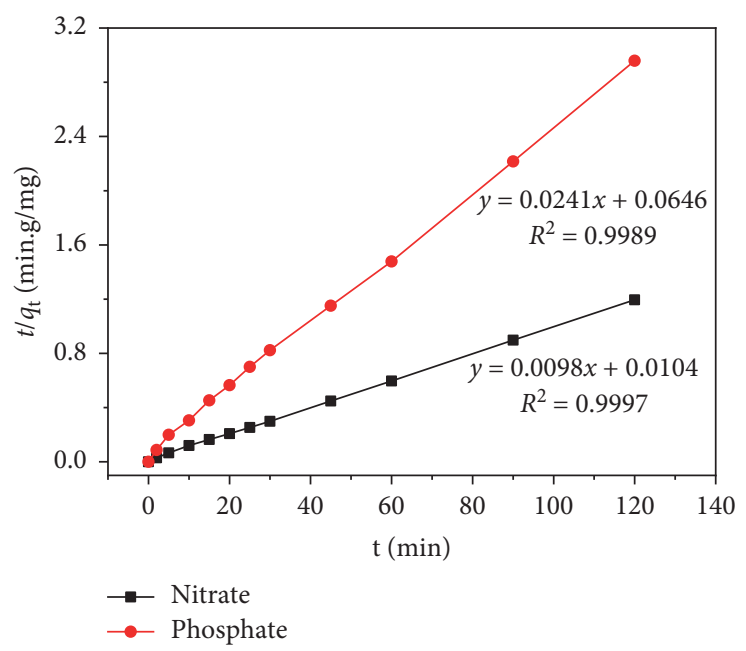

Figure 7: Pseudo-second-order kinetic plot of nitrate and phosphate adsorption onto ferric oxide-amine material.

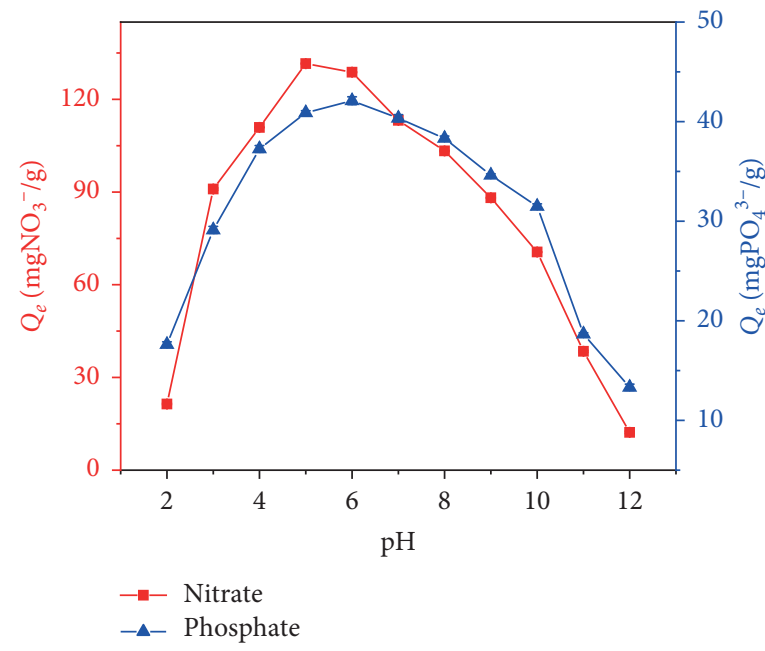

(a)

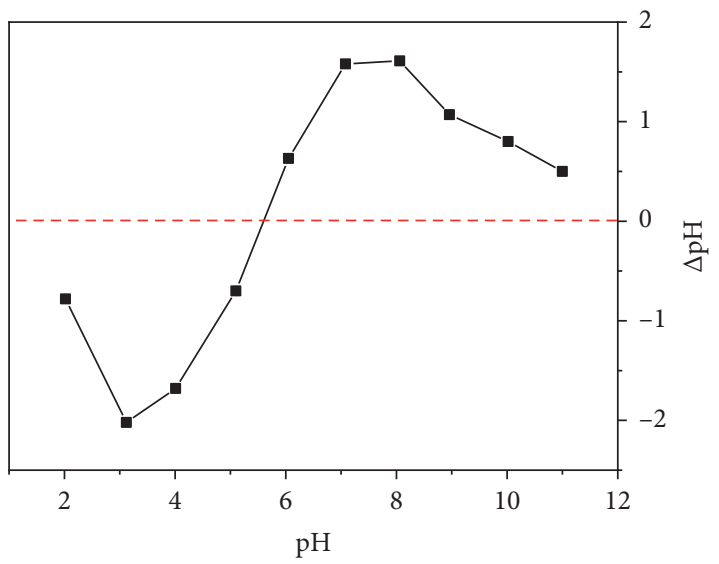

(b)

FIgURE 8: (a) Effects of initial solution $\mathrm{pH}$ on nitrate and phosphate adsorption. (b) The isoelectric point of ferric oxide-amine material.

account of an adsorption competition with $\mathrm{OH}^{-}$[31]. In the solution, phosphate anions dissociate into different forms depending on $\mathrm{pH}$. Major forms of phosphate are $\mathrm{H}_{3} \mathrm{PO}_{4}$, $\mathrm{H}_{2} \mathrm{PO}_{4}{ }^{-}, \mathrm{HPO}_{4}{ }^{2-}$, and $\mathrm{PO}_{4}{ }^{3-}$ at $\mathrm{pH}<2,2-7,7-11$, and $>11$, respectively [30]. In phosphate adsorption at $\mathrm{pH}<7$, $\mathrm{H}_{2} \mathrm{PO}_{4}{ }^{-}$was easily bonded to ferric oxide-amine by electrostatic forces $\left(\mathrm{pH}<\mathrm{pH}_{\mathrm{pzc}}\right)$ to increase phosphate adsorption capacity. At high $\mathrm{pH}$, phosphate adsorption capacity decreases due to the adsorption competition with $\mathrm{OH}^{-}$. In conclusion, the ferric oxide-amine had the highest adsorption capacity of nitrate and phosphate in the $\mathrm{pH}$ range of 5-6 and 6, respectively. The experiment to determine the isoelectric point value of the material in $0.01 \mathrm{~N} \mathrm{KCl}$ solution is shown in Figure $8(\mathrm{~b})$, where $\mathrm{pH}_{\mathrm{pzc}}$ of ferric oxide-amine 
was determined to be 5.8. At $\mathrm{pH}<\mathrm{pH}_{\mathrm{pzc}}$, the adsorbent surface is positively charged, so the adsorption process of nitrate and phosphate anions was based on electrostatic attraction mechanism. However, with the solution $\mathrm{pH}>\mathrm{pH}_{\mathrm{pzc}}$, the adsorption capacity decreases because of the negatively charged surface and the competition with $\mathrm{OH}^{-}$, which both inhibit the adsorption of anions such as nitrate and phosphate [32].

As displayed in Figure 9, the adsorption capacity was greatly influenced by the dosage of ferric oxide-amine. Decreases in adsorption capacity were experienced when the adsorbent dosage increased; however, at the time, the removal efficiency increased and the quality of the output water improved. In terms of nitrate adsorption, an output concentration of $27.10 \mathrm{mgNO}_{3}{ }^{-}-\mathrm{N} / \mathrm{L}$ was found when $30 \mathrm{mg}$ of absorbent was used, which met the nitrate requirement in column A of QCVN 14:2008/BTNMT. In phosphate adsorption, a good agreement with phosphate concentration in column A (lower than $6 \mathrm{mgPO}_{4}{ }^{3-}-\mathrm{P} / \mathrm{L}$ ) was also witnessed in the output concentration of phosphate. The phosphate adsorption capacity decreased rapidly with the increase of dosage from 5 to $30 \mathrm{mg}$ but then deceased slowly with a further increase of dosage from 30 to $100 \mathrm{mg}$. Therefore, $30 \mathrm{mg}$ of the material was chosen for subsequent experiments such as the effects of initial adsorbate concentration and solution temperature on adsorption capacity.

The effects of initial nitrate concentration and solution temperature on the adsorption capacity are exhibited in Figure 10(a), showing an increasing trend of adsorption capacity with the increases of initial concentration and temperature. The higher nitrate concentration facilitates the interaction between nitrate ions and adsorption sites of the material. Similarly, the nitrate ions in the solution become more mobile at higher temperatures, increasing the frequency of collisions between the material and the nitrate ions. This can be seen in solutions with a nitrate concentration of $100 \mathrm{mg} / \mathrm{L}$ or higher when the solution temperature increased from $20^{\circ} \mathrm{C}$ to $45^{\circ} \mathrm{C}$. In addition, it was seen clearly in Figure 10(b) that similarity to the nitrate adsorption capacity also occurred for phosphate. The phosphate adsorption capacity of the material was directly proportional to the ascending variations in the initial phosphate concentration and solution temperature. Favorable conditions for adsorption such as the increase in the mobility and density of phosphate ions, in short, can promote interaction between them and the material.

In this study, the Langmuir and Freundlich isotherm models were used to describe the correlation between nitrate and phosphate on the ferric oxide-amine surface and their equilibrium concentrations in the solution with a constant temperature. The isotherm adsorption parameters of the processes are presented in Table 2. Although both Langmuir and Freundlich models were suitable for describing nitrate adsorption, the Langmuir model was more fit on account of its higher correlation coefficients. Relatively high correlation coefficients of 0.9866 and 0.9982 were found in the Langmuir equation at $30^{\circ} \mathrm{C}$ for nitrate and phosphate, respectively. These results indicated that the ferric oxide-amine surface had uniformity, and a similar affinity for both nitrate and phosphate ions and the adsorption occurred mainly from the interaction of ions and the functional groups to create monolayer molecules on the ferric oxide-amine surface. The values of $n$ in the Freundlich model indicated the favorable condition for the adsorption process. The maximum adsorption capacities at $30^{\circ} \mathrm{C}$ were also compared with those reported previously and the results are presented in Table 3. It can be concluded that the maximum adsorption capacity of nitrate onto ferric oxide-amine was the highest among other adsorbents in the literature. However, phosphate adsorption onto this material was lower than that onto $\mathrm{MgO}$-biochar and nano-2D-MgO materials.

As regards adsorption thermodynamics, parameters such as Gibbs free energy $(\Delta G)$, entropy $(\Delta S)$, and enthalpy $(\Delta H)$ obtained using equilibrium constants at different temperatures (i.e., 293, 303, and $318 \mathrm{~K}$ ) are summarized in Table 4. In general, it is obvious that both nitrate and phosphate adsorption processes had $\Delta G<0$, proving the self-evolution process under standard conditions. On the other hand, the phosphate adsorption was an exothermic process with $\Delta H<0$ while the nitrate adsorption was an endothermic process with $\Delta H>0$ [38]. It is known that, with $\Delta H<40 \mathrm{~kJ} / \mathrm{mol}$, the adsorption process is usually considered as physical adsorption. Besides, the affinity of the adsorbent for nitrate and phosphate is expressed by the value of $\Delta S$ [39].

3.3. Competitive Adsorption and Application to Real Wastewater. Some common anions in wastewater such as $\mathrm{Cl}^{-}, \mathrm{SO}_{4}{ }^{2-}$, and $\mathrm{HCO}_{3}{ }^{-}$are usually competitors during the adsorption of target nitrate and phosphate. Therefore, to assess the influence level of the competing ions, it is necessary to conduct a test with the solution containing the above anions. The amount of material used was about $30 \mathrm{mg}$ in $50 \mathrm{~mL}$ of the solution with nitrate and phosphate concentration of $50 \mathrm{mg} / \mathrm{L}$ and $100 \mathrm{mg} / \mathrm{L}$, respectively. As exhibited in Figure 11, the adsorption capacity of ferric oxide-amine was affected at different levels by these anions. Among the anions, sulfate had the greatest influence on phosphate adsorption of the material, making its adsorption capacity reduce by nearly $1 / 3$ from $152.04 \mathrm{mg} / \mathrm{g}$ to only $43.74 \mathrm{mg} / \mathrm{g}$. Although chloride has a maximum electronic affinity, sulfate was proven to have a greater competitive effect on phosphate adsorption [40]. Meanwhile, the effect of the other three anions (i.e., chloride, sulfate, and bicarbonate) on the nitrate adsorption capacity of ferric oxideamine was almost similar. The adsorption capacity, more specifically, decreased by $25 \%$ from $135 \mathrm{mg} / \mathrm{g}$ to roughly $100 \mathrm{mg} / \mathrm{g}$.

Nitrate and phosphate removal efficiencies from synthetic and real wastewater by ferric oxide-amine material as compared to ferric oxide and anion exchange resin (Akualite A420) are illustrated in Figure 12. The results indicated that all three materials had the ability to simultaneously adsorb nitrate and phosphate anions, especially ferric oxide-amine which had quantitatively superior nitrate adsorption capacity compared to ferric oxide and Akualite A420. In synthetic wastewater (Figure 12(a)), nitrate and phosphate 


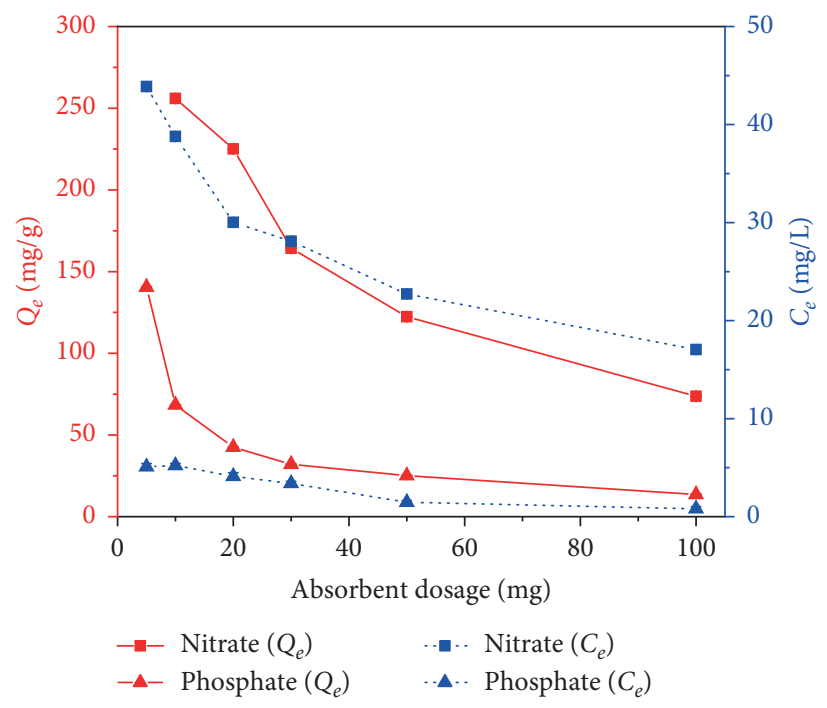

FIGURE 9: Remaining concentration and adsorption capacity of nitrate and phosphate at different adsorbent dosages.

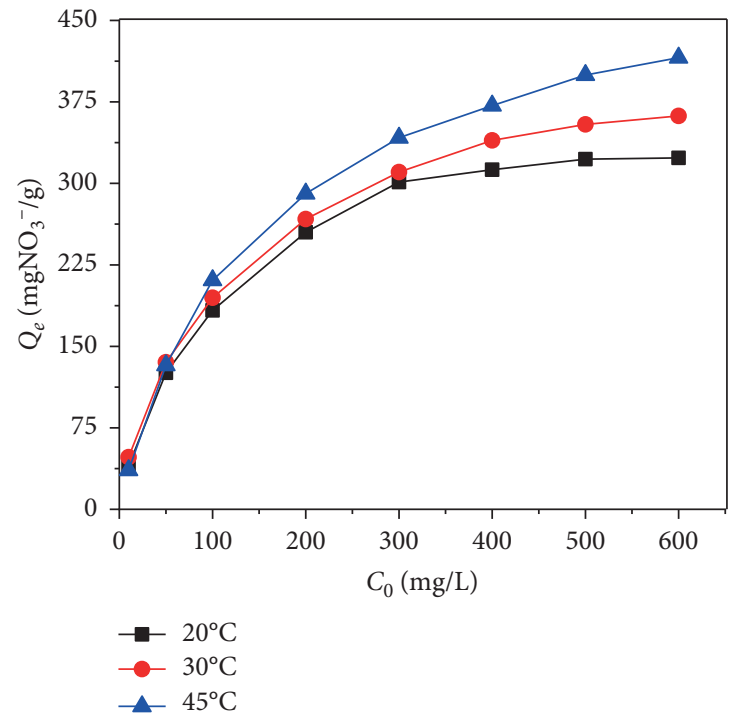

(a)

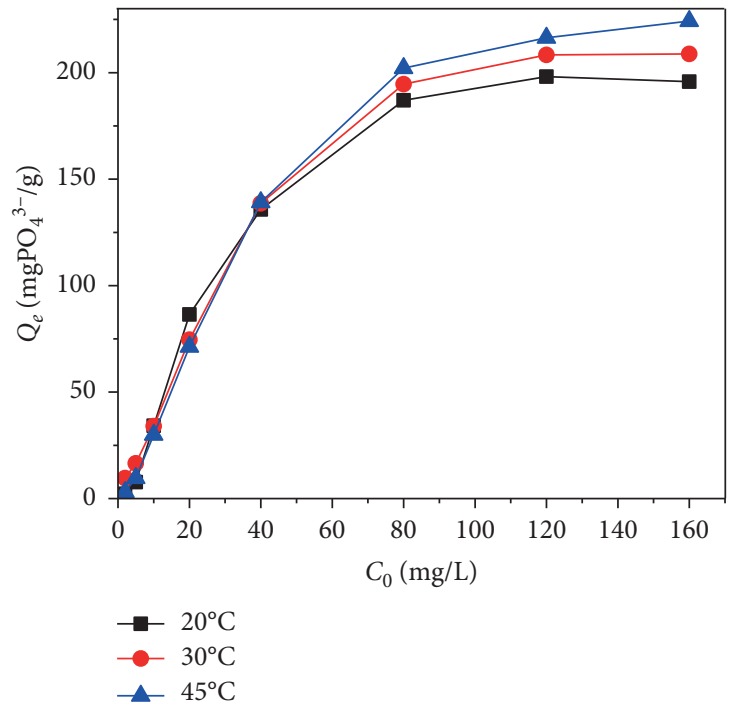

(b)

FIGURE 10: (a) Nitrate and (b) phosphate adsorption capacity of ferric oxide-amine material at different initial concentrations and solution temperatures.

adsorption capacity of the materials can be arranged in descending order as ferric oxide-amine $>$ Akualite A420 > ferric oxide for nitrate and ferric oxide $>$ ferric oxideamine $>$ Akualite A420 for phosphate. The nitrate adsorption capacity of ferric oxide-amine was 20 times higher than that of ferric oxide and 4 times higher than that of Akualite A420. The phosphate adsorption capacity of ferric oxideamine $(19.43 \mathrm{mg} / \mathrm{g})$ was lower than that of ferric oxide $(28.06 \mathrm{mg} / \mathrm{g})$, but it was still 4 times higher than that of Akualite A420. While ferric oxide had the nitrate adsorption capacity much less than the phosphate adsorption capacity, both ferric oxide-amine and Akualite A420 had a nitrate adsorption capacity superior to the phosphate adsorption capacity. In real wastewater (Figure 12(b)), the nitrate adsorption capacity of ferric oxide-amine was still the highest, but it was reduced compared to that of the other materials on this account. There may be some other ions and small amounts of organic matter in the wastewater, which led to adsorption competition as discussed above. The ferric oxide after being grafted with amine-functional groups had much higher adsorption capacity than the original one, but its phosphate adsorption capacity remained the same at $20 \mathrm{mg} / \mathrm{g}$, proving that amine groups mainly interacted with nitrate ions [41] whereas most phosphate ions interacted with ferric oxide [42]. As also depicted in Figure 12(b), it can be said that all ferric oxide, ferric oxide-amine, and Akualite A420 materials can remove the COD content of real wastewater samples. The COD removal efficiency of ferric 
TABLE 2: The isotherm parameters of nitrate and phosphate adsorption onto ferric oxide-amine material.

\begin{tabular}{|c|c|c|c|c|}
\hline \multirow{2}{*}{ Isotherm } & \multirow{2}{*}{ Parameter } & \multicolumn{3}{|c|}{ Temperature $\left({ }^{\circ} \mathrm{C}\right)$} \\
\hline & & 20 & 30 & 45 \\
\hline \multicolumn{5}{|l|}{ Nitrate } \\
\hline \multirow{3}{*}{ Langmuir } & $Q_{\max }(\mathrm{mg} / \mathrm{g})$ & 357.4 & 400.00 & 476.19 \\
\hline & $K_{L}(\mathrm{~L} / \mathrm{mg})$ & 0.0044 & 0.0041 & 0.0030 \\
\hline & $R^{2}$ & 0.9974 & 0.9936 & 0.9967 \\
\hline \multirow{3}{*}{ Freundlich } & $K_{f}\left((\mathrm{mg} / \mathrm{g})(\mathrm{L} / \mathrm{mg})^{n}\right)$ & 0.0752 & 0.0542 & 0.1035 \\
\hline & $n$ & 2.3020 & 2.5075 & 1.9720 \\
\hline & $R^{2}$ & 0.9630 & 0.9866 & 0.9612 \\
\hline \multicolumn{5}{|l|}{ Phosphate } \\
\hline \multirow{3}{*}{ Langmuir } & $Q_{\max }(\mathrm{mg} / \mathrm{g})$ & 270.27 & 217.39 & 312.50 \\
\hline & $K_{L}(\mathrm{~L} / \mathrm{mg})$ & 0.0679 & 0.0679 & 0.0087 \\
\hline & $R^{2}$ & 0.8123 & 0.9982 & 0.9386 \\
\hline \multirow{3}{*}{ Freundlich } & $K_{f}\left((\mathrm{mg} / \mathrm{g})(\mathrm{L} / \mathrm{mg})^{n}\right)$ & 0.3693 & 0.0491 & 0.3204 \\
\hline & $n$ & 1.1939 & 2.2227 & 1.2288 \\
\hline & $R^{2}$ & 0.8669 & 0.9381 & 0.9528 \\
\hline
\end{tabular}

TABle 3: A comparison between $Q_{\max }$ in this study and previous research studies.

\begin{tabular}{|c|c|c|c|}
\hline Adsorbent & Nitrate $(\mathrm{mg} / \mathrm{g})$ & Phosphate (mg/g) & Reference \\
\hline Mix oxide $\mathrm{CeO}_{2}-\mathrm{Al}_{2} \mathrm{O}_{3}$ & - & 125.42 & [33] \\
\hline MgO-biochar & 94.00 & 835.00 & {$[34]$} \\
\hline Nanofiber chitosan $/ \mathrm{Al}_{2} \mathrm{O}_{3} / \mathrm{Fe}_{3} \mathrm{O}_{4}$ & 160.50 & 135.10 & {$[12]$} \\
\hline Amin-chitosan & 37.45 & 41.49 & {$[18]$} \\
\hline Exchange ions resin NDP-2 & 174.00 & - & {$[20]$} \\
\hline $\mathrm{Fe}_{3} \mathrm{O}_{4} @ \mathrm{Zn}-\mathrm{Al}-\mathrm{LDH}$ & - & 36.90 & {$[31]$} \\
\hline Iron-bentonite & - & 11.2 & {$[35]$} \\
\hline Particular chitosan & 113.10 & 58.50 & {$[36]$} \\
\hline Nano 2D MgO & - & 255.1 & [37] \\
\hline Ferric oxide-amine & 400.00 & 217.39 & This study \\
\hline
\end{tabular}

TABLE 4: Thermodynamic parameters of nitrate and phosphate adsorption onto ferric oxide-amine material at different temperatures.

\begin{tabular}{lccc}
\hline Thermodynamic parameter & Temperature $(\mathrm{K})$ & Nitrate & Phosphate \\
\hline & 293 & -0.01 & -3.84 \\
$\Delta G(\mathrm{~kJ} / \mathrm{mol})$ & 303 & -0.08 & -3.4 \\
& 318 & -0.19 & -2.74 \\
$\Delta H(\mathrm{~kJ} / \mathrm{mol})$ & - & 2.13 & -16.75 \\
$\Delta S(\mathrm{~kJ} / \mathrm{mol} . \mathrm{K})$ & - & 0.007 & -0.04 \\
\hline
\end{tabular}

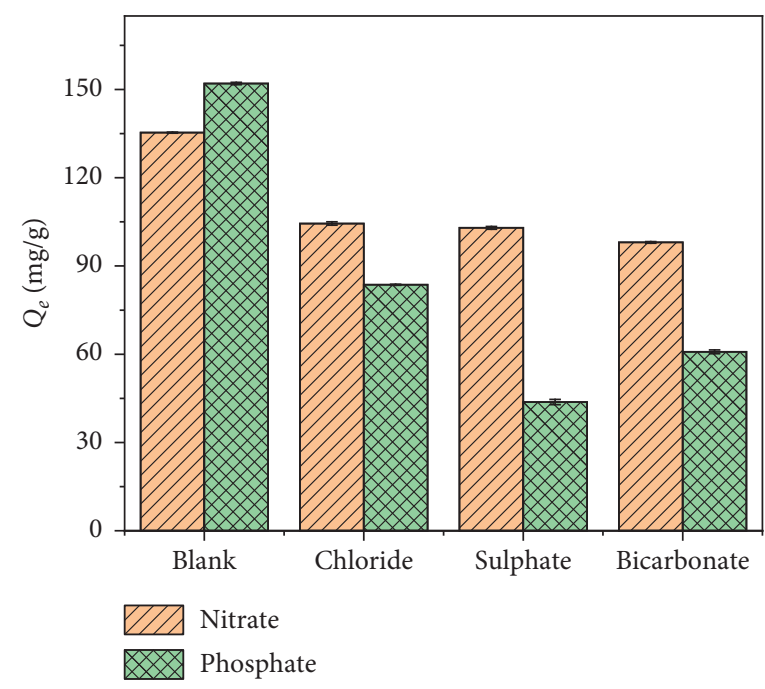

FIGURE 11: Effect of coexisting anions on nitrate and phosphate adsorption capacity of ferric oxide-amine material. 


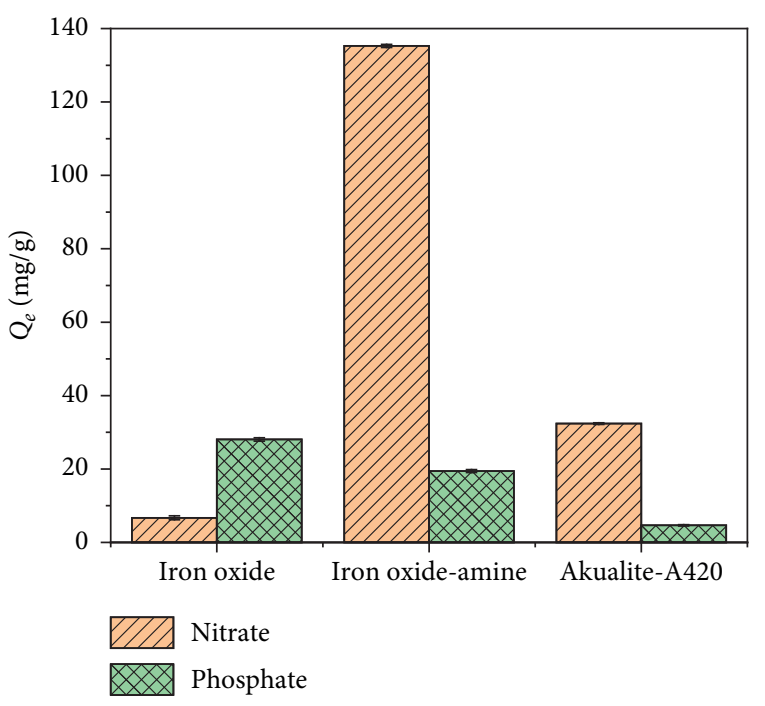

(a)

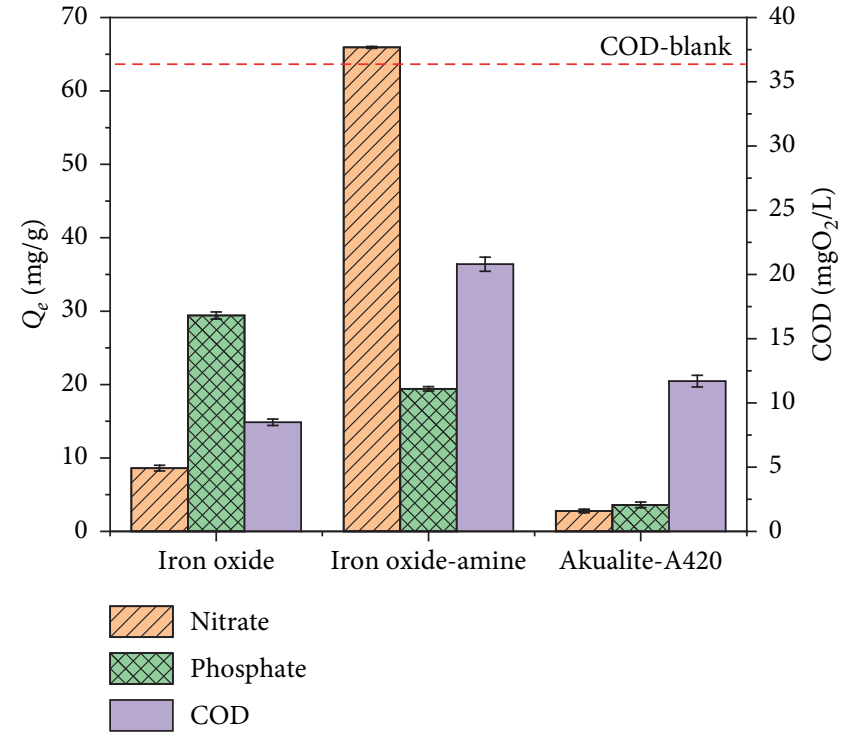

(b)

Figure 12: (a) Nitrate and phosphate adsorption capacity in synthetic wastewater; (b) nitrate and phosphate adsorption capacity in real wastewater, and COD of real wastewater before and after adsorption of ferric oxide, ferric oxide-amine, and Akualite A420 resin.

oxide was the highest one, which was followed by Akualite A420 and then ferric oxide-amine. This also implies that ferric oxide-amine was less affected by organic matter in wastewater than ferric oxide and Akualite A420 under the same conditions.

\section{Conclusions}

Ferric oxide-amine materials were successfully synthesized and characterized by SEM, EDX, FTIR, XRD, TGA, and BET analyses. The equilibrium time for nitrate and phosphate adsorption was $30 \mathrm{~min}$ and $60 \mathrm{~min}$, respectively, while the suitable $\mathrm{pH}$ was in the range of 5 to 6 for nitrate and $\mathrm{pH} 6$ for phosphate. The adsorption capacity increased with the increase of nitrate and phosphate concentration and temperature but decreased with the increase of adsorbent dosage. When compared with commercial Akualite A420, ferric oxide-amine material showed outstanding nitrate and phosphate adsorption capacity, which can find many applications in water and wastewater treatment.

\section{Data Availability}

The experimental data used to support the findings of this study are included in the manuscript. The other data are available from the corresponding author upon request.

\section{Conflicts of Interest}

The authors declare that there are no conflicts of interest regarding the publication of this paper.

\section{Acknowledgments}

This research was funded by Vietnam National University Ho Chi Minh City under grant no. A2020-16-01.

\section{References}

[1] S. E. Jørgensen, W. D. Williams, UIET Centre, and ILE Committee, Lakes and Reservoirs: Water Quality: The Impact of Eutrophication, UNEP-International Environment Technology Centre, Osaka, Japan, 2001.

[2] D. Majumdar and N. Gupta, "Nitrate pollution of groundwater and associated human health disorders," Indian Journal of Environmental Health, vol. 42, no. 2, pp. 28-39, 2000.

[3] J. P. Bassin, R. Kleerebezem, M. Dezotti, and M. C. M. Van Loosdrecht, "Simultaneous nitrogen and phosphate removal in aerobic granular sludge reactors operated at different temperatures," Water Research, vol. 46, no. 12, pp. 3805-3816, 2012.

[4] X. Xu, B.-Y. Gao, Q.-Y. Yue, and Q.-Q. Zhong, "Preparation of agricultural by-product based anion exchanger and its utilization for nitrate and phosphate removal," Bioresource Technology, vol. 101, no. 22, pp. 8558-8564, 2010.

[5] E. Lacasa, P. Cañizares, C. Sáez, F. J. Fernández, and M. A. Rodrigo, "Removal of nitrates from groundwater by electrocoagulation," Chemical Engineering Journal, vol. 171, no. 3, pp. 1012-1017, 2011.

[6] E. N. Peleka, P. P. Mavros, D. Zamboulis, and K. A. Matis, "Removal of phosphates from water by a hybrid flotationmembrane filtration cell," Desalination, vol. 198, no. 1-3, pp. 198-207, 2006.

[7] A. Sowmya and S. Meenakshi, "Removal of nitrate and phosphate anions from aqueous solutions using strong base anion exchange resin," Desalination and Water Treatment, vol. 51, no. 37-39, pp. 7145-7156, 2013.

[8] H. T. Banu and S. Meenakshi, "Synthesis of a novel quaternized form of melamine-formaldehyde resin for the removal of nitrate from water," Journal of Water Process Engineering, vol. 16, pp. 81-89, 2017.

[9] M. Kalaruban, P. Loganathan, W. G. Shim et al., "Removing nitrate from water using iron-modified dowex $21 \mathrm{~K}$ XLT ion exchange resin: batch and fluidised-bed adsorption studies," Separation and Purification Technology, vol. 158, pp. 62-70, 2016. 
[10] M. Nujic, D. Milinkovic, and M. Habuda-Stanic, "Nitrate removal from water by ion exchange," Croatian Journal of Food Science and Technology, vol. 9, no. 2, pp. 182-186, 2017.

[11] V. K. Gupta, S. Agarwal, and T. A. Saleh, "Chromium removal by combining the magnetic properties of iron oxide with adsorption properties of carbon nanotubes," Water Research, vol. 45, no. 6, pp. 2207-2212, 2011.

[12] F. Bozorgpour, H. F. Ramandi, P. Jafari, S. Samadi, S. S. Yazd, and M. Aliabadi, "Removal of nitrate and phosphate using chitosan/ $\mathrm{Al} 2 \mathrm{O}$ 3/Fe $3 \mathrm{O} 4$ composite nanofibrous adsorbent: comparison with chitosan/Al 2 O 3/Fe 3 O 4 beads," International Journal of Biological Macromolecules, vol. 93, pp. 557-565, 2016.

[13] P. K. Raul, R. R. Devi, I. M. Umlong, S. Banerjee, L. Singh, and M. Purkait, "Removal of fluoride from water using iron oxidehydroxide nanoparticles," Journal of Nanoscience and Nanotechnology, vol. 12, no. 5, pp. 3922-3930, 2012.

[14] P. K. Raul, R. R. Devi, I. M. Umlong, A. J. Thakur, S. Banerjee, and V. Veer, "Iron oxide hydroxide nanoflower assisted removal of arsenic from water," Materials Research Bulletin, vol. 49 , pp. $360-368,2014$.

[15] N. T. Thanh, "Amine-bearing activated rice husk ash for $\mathrm{CO}_{2}$ and $\mathrm{H}_{2} \mathrm{~S}$ gas removals from biogas," Engineering and Applied Science Research, vol. 43, pp. 396-398, 2016.

[16] H. Hifumi, A. V. Ewing, and S. G. Kazarian, "ATR-FTIR spectroscopic imaging to study the drying and dissolution of pharmaceutical polymer-based films," International Journal of Pharmaceutics, vol. 515, no. 1-2, pp. 57-68, 2016.

[17] Y. Arai and D. L. Sparks, "ATR-FTIR spectroscopic investigation on phosphate adsorption mechanisms at the ferrihydrite-water interface," Journal of Colloid and Interface Science, vol. 241, no. 2, pp. 317-326, 2001.

[18] I. Aswin Kumar and N. Viswanathan, "Development and reuse of amine-grafted chitosan hybrid beads in the retention of nitrate and phosphate," Journal of Chemical \& Engineering Data, vol. 63, no. 1, pp. 147-158, 2018.

[19] P. X. Nui, L. V. Son, and T. T. V. Thi, "Synthesis and characterization of (3-aminopropyl) Triethoxysilane coated magnetite nanoparticles for drug delivery," VNU Journal of Science: Natural Sciences and Technology, vol. 32, no. 4, pp. 143-150, 2016.

[20] H. Song, Y. Zhou, A. Li, and S. Mueller, "Selective removal of nitrate from water by a macroporous strong basic anion exchange resin," Desalination, vol. 296, pp. 53-60, 2012.

[21] M. F. Abou Taleb, G. A. Mahmoud, S. M. Elsigeny, and E.-S. A. Hegazy, "Adsorption and desorption of phosphate and nitrate ions using quaternary (polypropylene-g-N,Ndimethylamino ethylmethacrylate) graft copolymer," Journal of Hazardous Materials, vol. 159, no. 2-3, pp. 372-379, 2008.

[22] N. T. Hoan, B. A. Hoa, and N. S. Lam, "Effect of induration temperatures on the structure and quality of Narua-Caobang iron ore pellets," Science and Technology of Metals, vol. 79, pp. 35-40, 2018.

[23] R. V. Morris, H. V. Lauer, C. A. Lawson, E. K. Gibson, G. A. Nace, and C. Stewart, "Spectral and other physicochemical properties of submicron powders of hematite $(\alpha$-Fe2O3), maghemite $(\gamma$-Fe2O3), magnetite (Fe3O4), goethite $(\alpha-\mathrm{FeOOH})$, and lepidocrocite $(\gamma-\mathrm{FeOOH})$," Journal of Geophysical Research, vol. 90, pp. 3126-3144, 1985.

[24] J.-T. Anyanwu, Y. Wang, and R. T. Yang, "Amine-grafted silica gels for $\mathrm{CO}_{2}$ capture including direct air capture," Industrial \& Engineering Chemistry Research, vol. 59, no. 15, pp. 7072-7079, 2019.

[25] P. T. Phan, T. T. Nguyen, N. H. Nguyen, and S. Padungthon, "Triamine-bearing activated rice husk ash as an advanced functional material for nitrate removal from aqueous solution," Water Science and Technology, vol. 79, no. 5, pp. 850856, 2019.

[26] H. Jiang, H. Ma, Y. Jin, L. Wang, F. Gao, and Q. Lu, "Hybrid $\alpha-\mathrm{Fe}_{2} \mathrm{O}_{3} @ \mathrm{Ni}(\mathrm{OH})_{2}$ nanosheet composite for high-rate-performance supercapacitor electrode," Scientific Reports, vol. 6, no. 1, p. 31751, 2016.

[27] R. Siddheswaran, R. Medlín, P. Calta, and P. Šutta, "Preparation of $\mathrm{Nc}-\mathrm{Si} / \mathrm{A}-\mathrm{SiO}_{2}$ multi-layer thin film specimens for TEM cross-section observation by cryo argon ion slicing," Juniper Online Journal Material Science, vol. 1, no. 5, 2017.

[28] S. Sharmiladevi, A. Priya, and M. Sujitha, "Synthesis of mesoporous silica nanoparticles and drug loading for gram positive and gram negative bacteria International," Journal of Pharmacy and Pharmaceutical Sciences, vol. 8, pp. 196-201, 2016.

[29] A. Parma, I. Freris, P. Riello et al., "Structural and magnetic properties of mesoporous $\mathrm{SiO} 2$ nanoparticles impregnated with iron oxide or cobalt-iron oxide nanocrystals," Journal of Materials Chemistry, vol. 22, no. 36, pp. 19276-19288, 2012.

[30] Q. Zhang, Z. Zhang, J. Teng et al., "Highly efficient phosphate sequestration in aqueous solutions using nanomagnesium hydroxide modified polystyrene materials," Industrial \& Engineering Chemistry Research, vol. 54, no. 11, pp. 29402949, 2015.

[31] L.-G. Yan, K. Yang, R.-R. Shan et al., "Kinetic, isotherm and thermodynamic investigations of phosphate adsorption onto core-shell $\mathrm{Fe}_{3} \mathrm{O}_{4} @ \mathrm{LDH}$ composites with easy magnetic separation assistance," Journal of Colloid and Interface Science, vol. 448, pp. 508-516, 2015.

[32] A. Bravo, J. Garcia, X. Domenech, and J. Peral, "Some aspects of the photocatalytic oxidation of ammonium ion by titanium dioxide," Journal of Chemical Research, Synopses, vol. 9, pp. 376-377, 1993.

[33] D. N. Nhiem, N. T. H. Chi, D. T. Dung, N. D. Van, and D. T. Lim, "Adsorption of amino photphat $\left(\mathrm{PO}_{4}{ }^{3-}\right)$ from solution by $\mathrm{CeO}_{2}-\mathrm{Al}_{2} \mathrm{O}_{3}$ composite (in Vietnamese)," Vietnam Journal of Chemistry, vol. 54, no. 3, p. 387, 2016.

[34] M. Zhang, B. Gao, Y. Yao, Y. Xue, and M. Inyang, "Synthesis of porous $\mathrm{MgO}$-biochar nanocomposites for removal of phosphate and nitrate from aqueous solutions," Chemical Engineering Journal, vol. 210, pp. 26-32, 2012.

[35] L.-G. Yan, Y.-Y. Xu, H.-Q. Yu, X.-D. Xin, Q. Wei, and B. Du, "Adsorption of phosphate from aqueous solution by hydroxyaluminum, hydroxy-iron and hydroxy-iron-aluminum pillared bentonites," Journal of Hazardous Materials, vol. 179, no. $1-3$, pp. 244-250, 2010.

[36] A. Sowmya and S. Meenakshi, "Effective removal of nitrate and phosphate anions from aqueous solutions using functionalised chitosan beads," Desalination and Water Treatment, vol. 52, no. 13-15, pp. 2583-2593, 2014.

[37] S. Ahmed and A. Iqbal, "Synthesis of 2D magnesium oxide nanosheets: a potential material for phosphate removal," Global Challenges, vol. 2, no. 12, 2018.

[38] A. Sowmya and S. Meenakshi, "An efficient and regenerable quaternary amine modified chitosan beads for the removal of nitrate and phosphate anions," Journal of Environmental Chemical Engineering, vol. 1, no. 4, pp. 906-915, 2013.

[39] Z. Bekçi, Y. Seki, and M. K. Yurdakoç, "A study of equilibrium and FTIR, SEM/EDS analysis of trimethoprim adsorption onto K10," Journal of Molecular Structure, vol. 827, no. 1-3, pp. 67-74, 2007.

[40] I. A. Kumar and N. Viswanathan, "Fabrication of metal ions cross-linked alginate assisted biocomposite beads for selective 
phosphate removal," Journal of Environmental Chemical Engineering, vol. 5, no. 2, pp. 1438-1446, 2017.

[41] T. T. Nguyen, T. P. Phan, H. N. Le et al., "Characterizations and nitrate adsorption capacity of amine- $\mathrm{SiO}_{2}$ material," Science and Technology Development Journal-Natural Sciences, vol. 2, no. 5, pp. 171-176, 2018.

[42] H. Wang, X. Xu, Z. Ren, and B. Gao, "Removal of phosphate and chromium (vi) from liquids by an amine-crosslinked nano- $\mathrm{Fe}_{3} \mathrm{O}^{-}$biosorbent derived from corn straw," RSC Advances, vol. 6, no. 53, pp. 47237-47248, 2016. 